葉間に存在し診断困難であった良性限局性胸膜中皮腫の 1 例

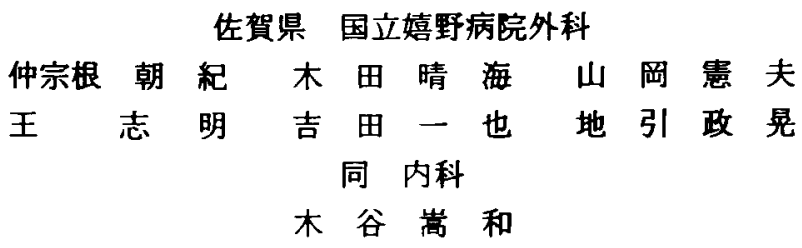

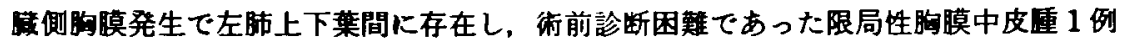

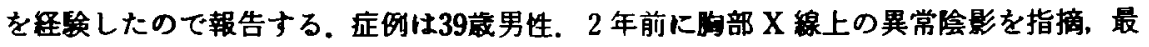
近陰影の增大㑯向が認められ当科紹介。胸部 X 線単純写真では左上肺野維隔側に extra pleural sign 陽性の均一な陰影があり，2 年前に比べて増大し陰影全体が䄪 $3 \mathrm{~cm}$ ほど下 方へ移動していた．右第 1 斜位像では左上下葉間に肺門に向かい毛筆様陰影を示し葉間

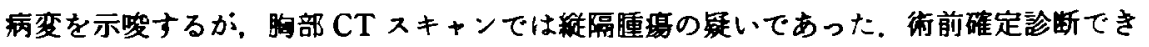
す開胸手術施行，畽留沬有茎性で左肺の上下葉間に挟まれるよ5に存在しており，正常

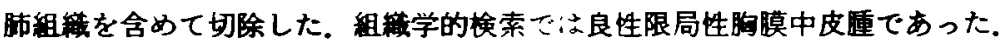

来引用語：限局性胸膜中皮腫，有茎性，葉間

\section{はじめに}

良性限局性朐莫中皮腫は，自覚症状に乏しく，娭診 などの朐部 X線写真にて異常陰影を指摘され発見さ れることが多い. 本症の診断にはX X 線所見での陰影の 移動、形状の変化な上が参考になると言われているが 実㗨容易ではない，当院です，左上下葉間に存在し，

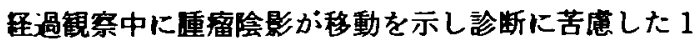
例を释験したので報告する。

\section{庭例}

患者：39歳男性.

主訴：的部 X 線上異常陰影。

家族歷：特記すべきことなし。

既往歴：同上.

現病歴：昭和60年 1 月始め頃より発熱，咳獭，左胸 痛か出現したため某医受診し、胸部 X 線写真にて左上 肺野に異常陰影を指摘された。抗生物質投与にて症状 は整快するが、陰影の消失はみられず当院内科を稆介 され経過襣察となる。昭和61年12月の検診で再度胸部 $\mathrm{X}$ 楾写真ての異常陰影を指摘され，昭和62年 1 月23日 前医受診し 2 年前に比べて陰影の增大を認められたた め62年 2 月27日当院外科に稆介された，当科では，就

1988年 8 月 1 日受付 1989 年 1 月13日採用
隔腫㻛または限局性脹湯の知いで外来にて释過観察し ていたか，さらに陰影の増大があり手術施行のため 月 1 日当科入院となる.

入院時現症：体格中等度．栄盖状態良好．体温 $36.7^{\circ} \mathrm{C}$, 眽拍 $78 / \mathrm{m}$, 整, 緊張良好. 呼吸数 $16 / \mathrm{m}$. 血圧 $126 / 80 \mathrm{mmHg}$. 眼䀫眼球結膜に貟血, 黄㡺を認めな かった，表在リンバ節の腫脹なし，胸郭の変形なく， 胸部聴打診上呼吸音, 心音に異常を認めなかった。腹 䛉:平坦, 軟. 䀒督脾も知しなかった。四肢関節痛, 太黄方指なく，神释学的異常も認めなかった。

入院時所見：血夜娭查にて RBC 475 万 $/ \mathrm{mm}^{3}, \mathrm{Hgb}$ $13.9 \mathrm{mg} / \mathrm{dl}$, Hct $42.7 \%$, WBC $5.400 / \mathrm{mm}^{3}$, Platelet $2.95 \times 10^{5} \mathrm{~mm}^{3}$ と異常を㒛めなかった，生化学的検查 では, T.P. 7.0g dl, T.B. 0.7mg, dl, GOT 21KU, GPT $18 \mathrm{KL}^{\circ}$, LDH 230WL. ALP 4.8KAU, CHE 1.0 $\Delta \mathrm{ph}$, Amylase 92somogi と異常を認めないが, $y$-gtp 152IU L L，LAP 203GRU と上昇を認めた，電解質，血 现、心電図，呼吸機能検查，動脈血ガス分析所見では 異常は認めなかった。昭和60年 1 月23日の胸部 X 線写 真では，左上肺野綎隔側に $30 \times 20 \mathrm{~mm}$ の均一な腫留陰 影を認め, extrapleural sign 陽性であった（図 1)，昭 和62年 7 月 6 日の胸部 X線写真では，陰影は50×50 $\mathrm{mm}$ と増大し全体が約 $3 \mathrm{~cm}$ ほど下方へ移動していた 


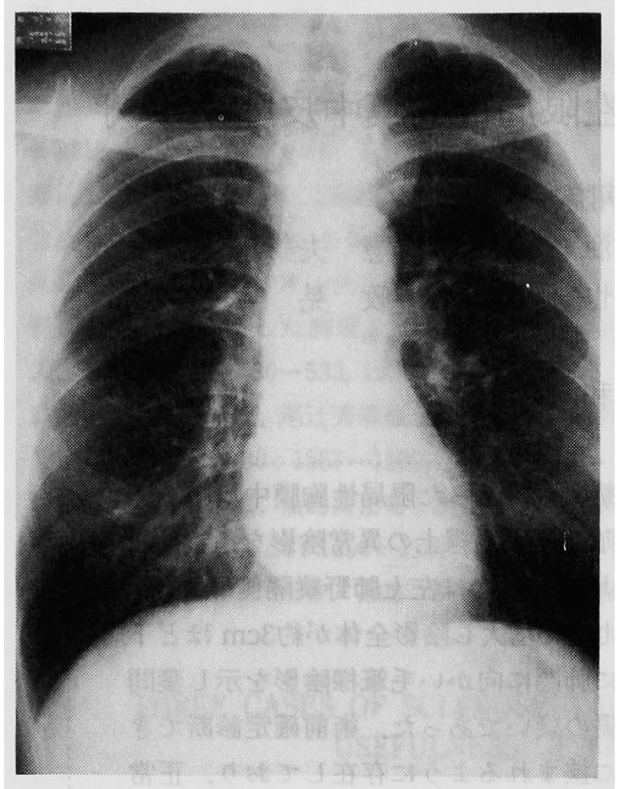

図 1 昭和60年 1 月23日の胸部単純写真：左上肺野緃 隔側に $30 \times 20 \mathrm{~mm}$ 大の均一な腫瘤陰影を認める。

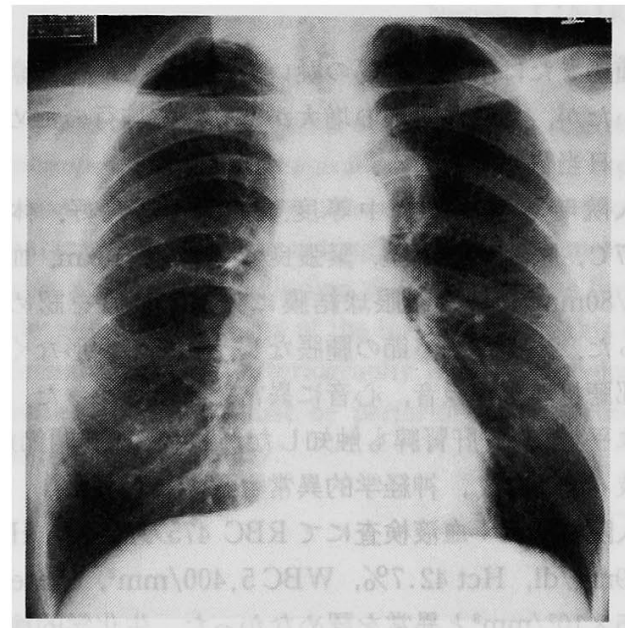

図 2 昭和62年 7 月 6 日の胸部単純写真：左上肺野の 畽瘤陰影は $50 \times 50 \mathrm{~mm}$ と増大し陰影全体が下方へ 移動している。

（図 2 ）。第 1 斜位像では，上下葉間に肺門へ向かい毛 筆様の均一な陰影を認め辺縁は明膫である(図 3)，第 2 斜位像では, $70 \times 50 \mathrm{~mm}$ の円形の均一な陰影を認め, はぼ辺縁明瞭であった（図 4 ）。左側面断層写真では, 胸壁より上下葉間にテント状に突出したような均一な 陰影あり，辺縁は明瞭であった（図 5 )。京た深呼吸，

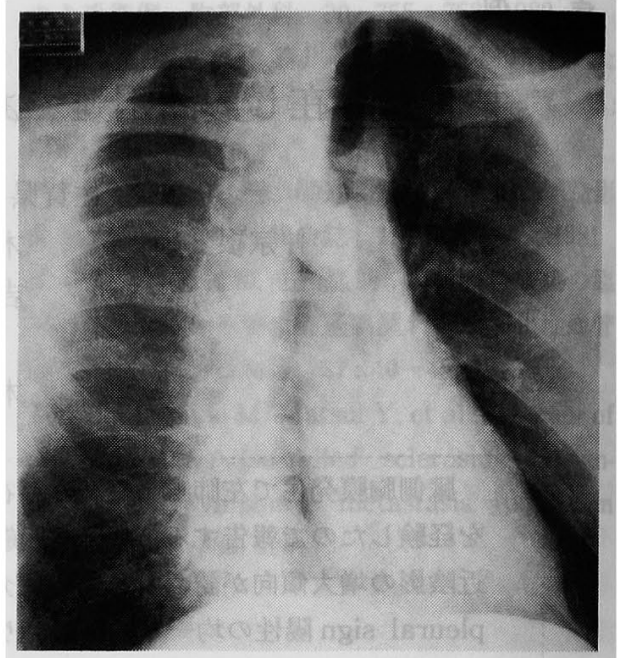

图 3 第 1 斜位像：肺門に向かい毛筆様の陰影を認め る.

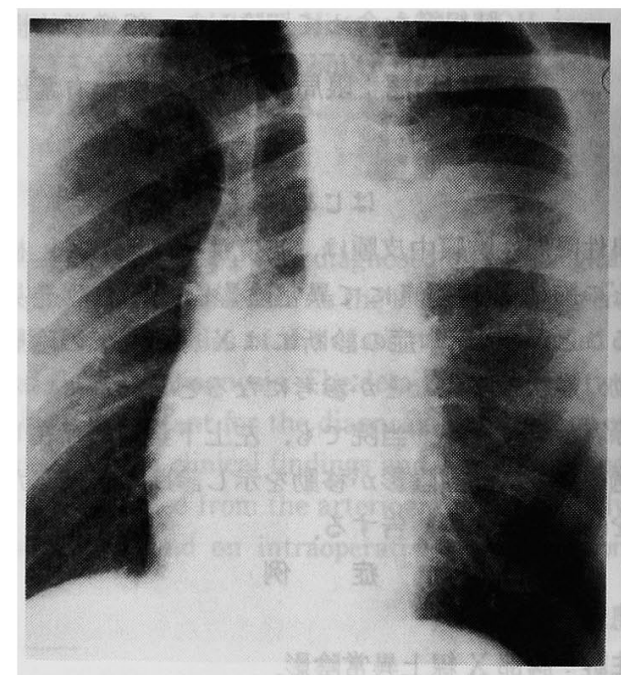

図 4 第 2 斜位像： $70 \times 50 \mathrm{~mm}$ 大の均一な腫瘤陰影 を認める。

体位变換による陰影の移動, 形状の变化は認められな かった，胸部 CT スキャン検査では，左胸部背維隔側 から立ち上がり滑らかな腫癉陰影があり，内部構造均 一で extrapleural sign 陽性であった. CT 值は, plain CT では mean 10前後, エンハンスメント CT では mean 50 と上界を示した（図 6 ）。胸部超音波検查ては 腫煬は同定できなかった，気管支，肋間動脈造影にて も濃染像, poolingなどは認めなかった，気管支造影， 気管支鏡検査, 喀痰細胞診でも異常所見を認めなかっ 


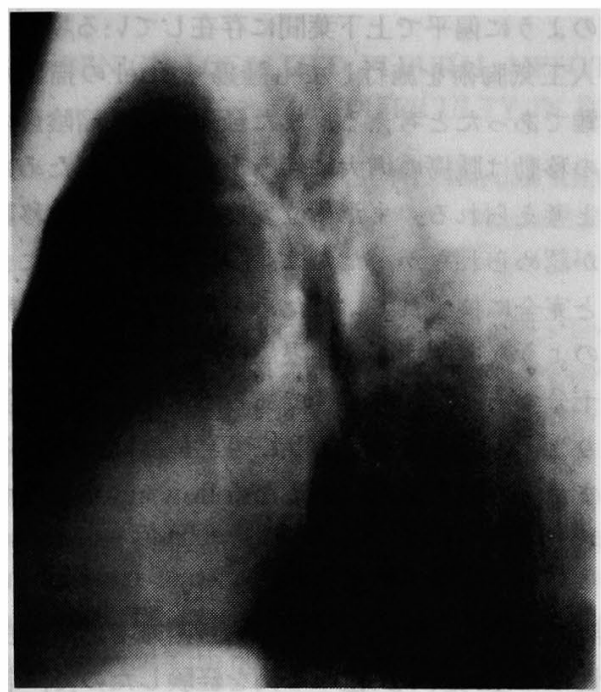

図 5 左側面断層写真：胸壁よりテント状に突出した 陰影を呈する.

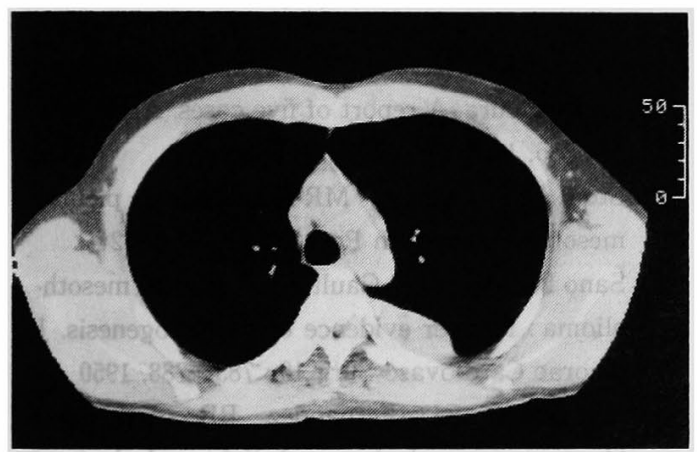

図 6 胸部 CT 像：綎隔側に extrapleural sign 陽性 の陰影を認める.

た. $\mathrm{Ga}$ シンチでも集積像は認められなかった. 以上の 所見より術前に確定診断には至らなかったが，腫瘍は 徐々に増大傾向であり悪性疾患も否定できないため, 穟隔腫瘍の疑いで昭和62年 7 月16日開胸手術を施行し た。

手術所見：全麻下に右側臥位として左腋窩切開，第 4 肋間にて開胸した。胸水, 胸膜癒着はない. 腫瘍は 左上葉 $\mathrm{S}^{1+2} \mathrm{c}$ 領域の葴側胸膜から発生し上下葉間に完 全に挟まれるように存在していた。キノコ状, 有茎性 であり，表面は臓側胸膜より連続性に被包化されてい た(図 7 )。術中, 限局性胸膜中皮腫と診断し, 茎付着 部で正常肺組織を含めて腫瘍切除した。

摘出標本所見：肉眼所見では, 腫瘍は大きさ $62 \times$

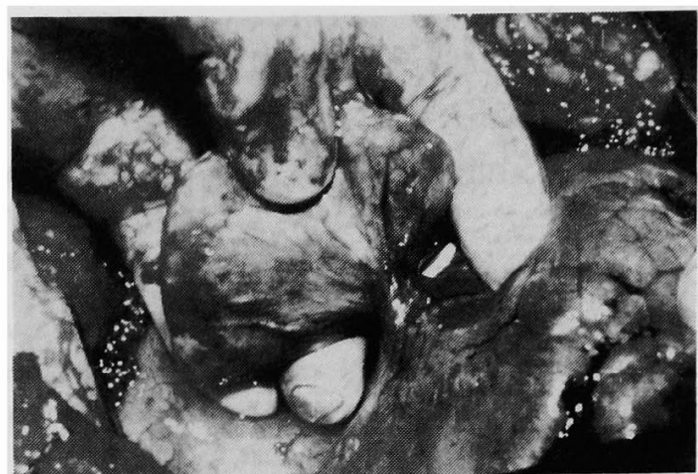

図 7 術中写真 : 左上葉 $\mathrm{S}^{1+2} \mathrm{C}$ 領域に上下葉間に挟ま れた有茎性の腫瘤を認める。

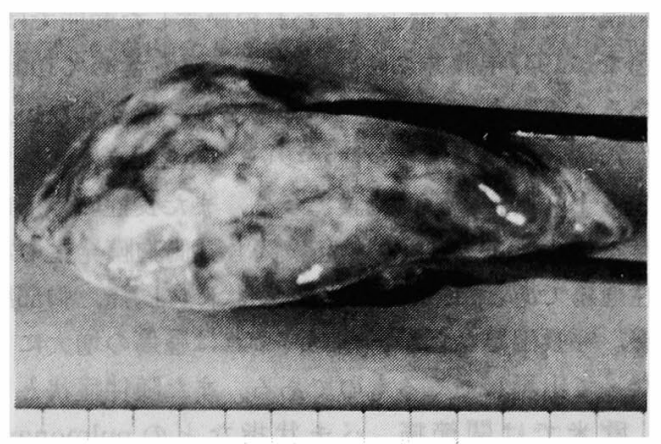

図 8 摘出標本：腫瘍は扁平, キノコ状

$52 \times 25 \mathrm{~mm}$, 有茥性, 弾性硬, 表面結節状で被膜を有し 茎部には動静脈を認める(図 8 )。割面は乳白色調を帯 び, 粘液を含む cysticlesionす小数認められる. 組織病 理学的所見では，紡錘型の腫瘍細胞が集簇ないしレー ス状に配列増殖し, 間質には種々の程度の膠原繊維の 増生をともなっている，個々の腫瘍細胞には異型性を 認めない，以上より良性限局性繊維性胸膜中皮腫之診 断された(図 9). 術後経過は良好であり, 現在術後 1 年を経過しているが再発は認めない。

\section{考案}

1931年 Klemperer 拈よび Rabin ${ }^{11}$ は胸膜中皮腫の 概念を明確に提唱し，び漫性胸膜中皮腫は中皮細胞由 来であり限局性胸膜中皮腫は胸膜下結合組織由来とし た。 それ以来, 限局性胸膜中皮腫の発生については, 今日まで種々の説が検討されている。限局性胸膜中皮 腫の組織培養により中皮細胞由来であるとする説2)3) や逆に纎維芽細胞由来であるといら説4)もあり, 現在 も発生母地については明確な結論がでていない。限局 


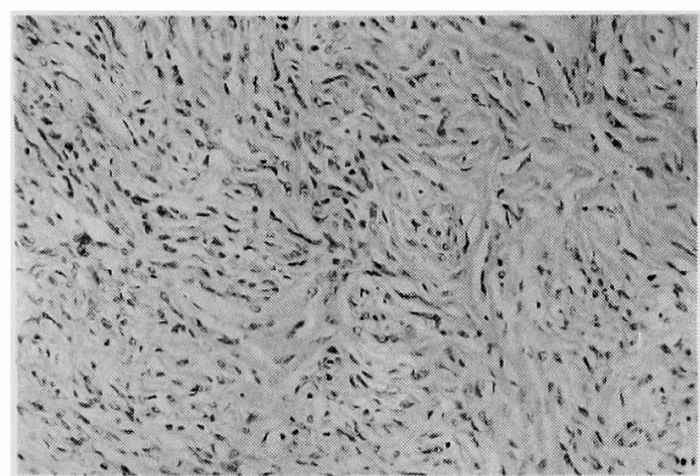

図 9 組織所見 (HE 染色)

性胸膜中皮腫は, 文献上われわれの検索した範囲では, 本邦では1947年篠井の報告以来自験例も含めて 100 例 である. 年齢も 16〜 77歳と広範であり, 性差はない. 良珄70例, 悪性30例と良性が多い, 発生部位について は2：1の割合で臓側胸膜に多く，また良性の腫瘍に は有茎性のものが多い5). 自験例も葴側胸膜発生の有 茎性腫瘍であった，本症の臨床症状には胸痛, 胸部圧 迫感，呼吸困難などがあるが，これは腫瘍の増大にと もなって出現してくるものである. また随伴症状とし て, 欧米では関節痛, バチ状指などの pulmonary osteoarthropathy や低血糖発作などがあるが本邦で は少ない6). 従って, 実際には自覚症状に乏しく，検診 などの胸部 X 線検査で初めて陰影を指摘され発見さ れることが多い、診断は容易ではなく，X 線所見で深 呼吸や体位変換に上る陰影の移動, 形状の変化, 特に 有茎性のものでは茎の存在が参考になると言われてい る. 自験例では, 1) 胸部 X 線写真での腫瘤陰影の特徵 より縦隔腫瘍及び葉間病変が疑われたが，2年間の経 過観察中に腫瘤陰影全体が $3 \mathrm{~cm}$ も下方へ移動を示し たことや，体位変換による陰影の移動，変形はみられ なかったことからこの腫瘤陰影の質的診断に苦慮し た. 2) 胸部 CT 所見では, 充実性で extrapleural sign は陽性であり造影所見陽性であることから血行豊富な 縦隔腫瘍を疑わせる．3）Ga シンチでも悪性所見は認 められない.4）腫瘍の発育は slow growing である.

これらのことから良性疾患とは思われたが, 緃隔疾 患か肺病変かの鑑別がつかず術前診断に苦慮した。文 献的には，人工気胸術や気縦隔造影が梲隔疾患と肺疾 患の鑑別に有用だと言われている7が，穿刺部よりの 腫瘍再発の危険性も報告されており ${ }^{8)}$, 本例では施行 しなかった. 手術後 retrospectiveに考えてみると，自
験例のよ5に偏平で上下葉間に存在している場合, た とえ人工気胸術を施行しても腫瘍や stiel の描出など は困難であったと考劣る。 また経過中の腫瘤陰影の下 方への移動は腫瘍の増大に伴う重量の増加のために生 じたと考学られる．また体位変換にても陰影の移動や 変形が認められなかったのは，腫瘍が上下葉間にきっ ちりと完全に挟まれていたためと推測された。治療は 本症のような有茎性の良性限局性胸膜中皮腫は腫湢切 除で十分であるが，有茎性であっても再発した報告例 はあり ${ }^{9)}$, 正常肺組織も含めて切除しなければならな い. また, 術後も長期間慎重な follow upが必要であ ると考える.

\section{おわりに}

本院において，葉間に存在し診断困難であった良性 限局性繊維性胸膜中皮腫の 1 例を経験したので, 若干 の文献的考察を加えて報告した。

尚, 本症例は第22回日本胸部疾患学会九州地方会 (長崎, 1987年11月）において発表した。

\section{文 献}

1) Klemperer $P$, Rabin $C R$ : Primary neoplasms of the pleura. A report of five cases. Arch Path $11: 385,1931$

2) Stout AP, Murray MR: Localized pleural mesothelioma. Arch Pathol 34 : 951, 1942

3) Sano ME, Weiss E, Gault ES : Pleural mesothelioma : Further evidence of its histogenesis. J Thorac Cardiovasc Surg 19: 783-788, 1950

4) Hernandez FJ, Fernandez BB: Localized fibrous tumors of pleura: A light and electron microscopic study. Cancer $34: 1667,1974$

5）木下雅俊, 宇山 正, 玉置 博他: 限局性胸膜中皮 腫の 5 例. 日胸臨 $46: 31-36,1987$

6) 藤本祐三郎, 秦 信輔, 松村晃秀他: Pulmonary Osteoarthropathy を呈した限局性胸膜中皮腫の 1 例. 胸部外科 $38: 733-736,1985$

7）伴場次郎, 友安 浩, 谷村繁雄他：前鋌隔腫瘍に酷 似した限局型胸膜中皮腫の $\mathrm{X}$ 線学的診断：日胸 臨 42:1047-1051, 1983

8）伴場次郎, 友安 浩, 谷村繁雄他：術後経過まれな 有茎性限局型胸膜中皮腫の 1 例. 日胸外会誌 34 : 272-276, 1986

9) Utley JR, Parker JC Jr, Harn RS, et al : Recurrent benign fibrous mesothelioma of the pleura. J Thorac Cardiovasc Surg 65: 830-834, 1973 


\title{
BENIGN LOCALIZED PLEURAL MESOTHELIOMA EXISTED IN INTER LOBAR SPACE WITH A DIFFICULTY IN DIAGNOSIS -REPORT OF A CASE-
}

\author{
Tomonori NAKASONE, Harumi KIDA, Norio YAMAOKA, Shimei OH, Kazuya YOSHIDA, \\ Masaaki JIBIKI and Takakazu KIYA* \\ Department of Surgery, and Internal Medicine*, Ureshino National Hospital
}

A case of benign localized pleural mesothelioma which was found in the visceral pleura between left upper and lower lobe is reported. A 39-year-old man was pointed out an abnormal lung shadow in the chest X-ray film two years ago. He was referred to our ward for a recent enlargement of the shadow. A plain chest film revealed a homogenous shadow with positive extrapleural sign in the left superior mediastinum. The shadow had enlarged and moved downward by about $3 \mathrm{~cm}$ during two years. Right anterior oblique projection showed a wrighting brush-like shadow toward the hilus which suggested an interlobar disease, but chest CT scan suggested a mediastinal tomor. Since it was difficult to make an established diagnosis preoperatively, thoracotomy was prformed. There was a pedunculated mass in the visceral pleura between left upper and lower lobe, and the mass was removed with normal lung tissue. Histological examination could confirm that it was a benign localized fibrous mesothelioma. 